\title{
Michał Kiedrzynek
}

ORCID: 0000-0001-9214-2820

Uniwersytet Humanistyczno-Przyrodniczy im. Jana Długosza w Częstochowie

https://doi.org/10.19195/1733-5779.35.18

\section{Ochrona środowiska w przepisach rangi konstytucyjnej w państwach byłej Jugosławii}

\section{JEL Classification: K32}

Słowa kluczowe: prawo ochrony środowiska, prawo administracyjne, prawo konstytucyjne

Keywords: environmental law, administrative law, constitutional law

\begin{abstract}
Abstrakt: W wyniku rozpadu Jugosławii powstało kilka niepodległych państw. Jednak ich droga do niepodległości przebiegała w różny sposób. Niektóre obrały kierunek prozachodni, przystępując do NATO i Unii Europejskiej, inne zaś wybrały kierunek wschodni, wzmacniając relacje z Federacją Rosyjską. W różny sposób uregulowane zostały także zagadnienia dotyczące ochrony środowiska w ustawach zasadniczych. Nasuwają się pytania związane z tym, jak wyglądają obecnie regulacje dotyczące ochrony środowiska w państwach, które jeszcze ćwierć wieku temu stanowiły jedność, oraz z tym, w jak wyczerpującym stopniu zagadnienie to zostało uregulowane na poziomie konstytucyjnym w poszczególnych krajach.
\end{abstract}

\section{Environmental protection in constitutional status in former Yugoslavian countries}

\begin{abstract}
As a result of the disintegration of Yugoslavia, a number of independent states were formed. However, their path to independence ran differently. Some of the countries took the pro-Western direction by joining NATO and the European Union, while others chose the Eastern direction, strengthening relations with the Russian Federation. The issues related to environmental protection in basic acts have also been regulated in various ways. There are a number of questions related to the current regulations on environmental protection in countries which were a unity a quarter of a century ago, and how comprehensive the issue was at the constitutional level in individual countries.
\end{abstract}

\section{Wstęp}

Upadek bloku wschodniego w 1989 roku skutkował nie tylko transformacją ustrojową i gospodarczą państw europy środkowej i wschodniej, lecz również 
w niektórych przypadkach ich rozpadem. Dezintegracja dotknęła Związek Socjalistycznych Republik Radzieckich, nieco później także Czechosłowację. Taka sytuacja miała miejsce również w przypadku Jugosławii, od której stopniowo odłączały się kolejne państwa. Efektem tego rozpadu była trwająca wiele lat wojna, która odcisnęła piętno na stosunkach pomiędzy narodami zamieszkującymi tamtejsze terytorium. $Z$ byłej Jugosławii wydzieliły się następujące państwa: Słowenia, Chorwacja, Serbia, Czarnogóra, Macedonia, Bośnia i Hercegowina oraz Kosowo, którego status międzynarodowy jest przedmiotem sporów1.

Losy wspomnianych państw potoczyły się różnie — Słowenia jest zamożnym i stabilnym krajem, który w 2004 roku dołączył zarówno do Unii, jak i do NATO. Chorwacja kilka lat później również wstąpiła do Unii i NATO, Czarnogóra zaś aspiruje do dołączenia do Unii Europejskiej, a członkiem NATO jest od 2017 roku. Bośnia i Hercegowina po wyniszczającej wojnie również zorientowała swoją politykę zagraniczną w kierunku zachodnim. Z kolei Serbia swoją politykę międzynarodową określiła w kierunku wschodnim, wiążąc nadzieje z Federacją Rosyjską. Doświadczenia i wybrane kierunki w polityce zagranicznej mają wpływ na kształt prawodawstwa w poszczególnych krajach.

Od wielu lat problematyka ochrony środowiska naturalnego stanowi przedmiot zainteresowania społecznego. Jednym z jego wyrazów jest powstawanie coraz rozleglejszych regulacji z zakresu prawnej ochrony środowiska. Tworzenie warunków dla ochrony środowiska znajduje także wyraz w przepisach rangi ustawy zasadniczej. Obecnie odniesienia do ochrony środowiska można odnaleźć w znacznej większości konstytucji państw. Wszystkie kraje byłej Jugosławii w swoich ustawach zasadniczych odnoszą się do kwestii ochrony środowiska. Jednak sposób i zakres regulacji w poszczególnych państwach jest odmienny. Niniejsze opracowanie będzie więc badaniem i porównaniem przepisów odnoszących się do ochrony środowiska w konstytucjach państw byłej Jugosławii. Badania te dają wyrazić się w następujących zagadnieniach badawczych:

1. hipoteza o braku oddziaływania regulacji zawartych w porządku prawnym Jugosławii na rozwiązania zawarte w ustawach zasadniczych poszczególnych państw;

2. hipoteza o braku możliwości bezpośredniego stosowania przepisów konstytucyjnych dotyczących ochrony środowiska - konieczność stworzenia ustawodawstwa całościowo regulującego omawianą materię;

3. hipoteza o donioślejszej roli przepisów z zakresu ochrony środowiska w porządkach ustrojowych Słowenii i Chorwacji względem reszty państw byłej Jugosławii.

Badania nad porządkiem ustrojowym państw byłej Jugosławii będą opierały się na analizie i porównaniu tekstów konstytucji poszczególnych krajów. Uwzględ-

1 P. Pacuła, Kosowo: problemy teraźniejszości, wyzwania przyszłości, „Bezpieczeństwo Narodowe" 22, 2012, s. $111 \mathrm{n}$. 
niony zostanie także dotychczasowy dorobek literatury i orzecznictwa dotyczący ustrojów poszczególnych państwa w zakresie ochrony środowiska. Sformułowane zostaną także wnioski i wskazówki, które ustrojodawcy w poszczególnych państwach powinni uwzględnić.

\section{Ochrona środowiska w ustawach zasadniczych Jugosławii}

W okresie funkcjonowania Socjalistycznej Federacyjnej Republiki Jugosławii obowiązywało kilka ustaw zasadniczych. Pierwszą z nich była Konstytucja Federacyjnej Ludowej Republiki Jugosławii z 31 stycznia 1946 roku, która po raz pierwszy określiła charakter ustrojowy państwa na następne kilkadziesiąt lat ${ }^{2}$. Kolejną ustawę zasadniczą uchwalono w 1953 roku wskutek konfliktu ze Związkiem Socjalistycznych Republik Radzieckich i innymi krajami Rady Wzajemnej Pomocy Gospodarczej ${ }^{3}$. Wprowadziła ona nowe elementy ustrojowe (na przykład dużą autonomię zakładów pracy), które z niewielkimi zmianami pozostały charakterystyczne dla tego państwa ${ }^{4}$. Kolejna konstytucja weszła w życie w 1963 roku i zakładała dalszą decentralizację oraz liberalizację ustroju społeczno-gospodarczego (przynajmniej w odniesieniu do innych państw bloku wschodniego) ${ }^{5}$. Utrzymanie samorządności jako podstawy ustroju można było rozpoznać także w Konstytucji z 21 lutego 1974 roku ${ }^{6}$. Częstotliwość zmian ustrojowych stanowiła ewenement w skali bloku wschodniego ${ }^{7}$. Konstytucja z 1974 roku była również pierwszą w tym kraju, w której uwzględniono potrzebę ochrony środowiska. Zawarte w części wstępnej „Zasady Podstawowe” w pkt V wskazywały, że

2 „Przede wszystkim potwierdzała związkowy charakter państwa jako federacji równouprawnionych republik. Ukształtowały się one faktycznie jeszcze przed proklamowaniem FLRJ poprzez powołanie republikańskich antyfaszystowskich rad narodowowyzwoleńczych i ich organów wykonawczych [...]. W tej pierwszej konstytucji nie użyto słowa »socjalizm«, lecz faktycznie poprzez formułę ludowładztwa miała ona charakter socjalistyczny”. Z. Rutyna-Frelek, Powstanie Socjalistycznej Federacyjnej Republiki Jugosławii, Warszawa 1985, s. 93.

${ }_{3}$ Zob. Konstytucja Federacyjnej Ludowej Republiki Jugosławii, przeł. N. Sandulovič, E. Kamiński, Warszawa 1957.

4 „Konstytucja z 1953 r. zapowiadała również zmianę charakteru własności środków produkcji z państwowej na społeczną. W samej ustawie zasadniczej własność społeczną (nie państwową) i samorząd robotniczy potraktowano jako dwa główne filary systemy społeczno-ekonomicznego państwa”, B. Ryś, Jugostowiański system samorzadowy, Warszawa 1986, s. 18.

5 Zob. T. Szymczak, Jugostawia - państwo federacyjne, Łódź 1982, s. 135 n.

${ }^{6}$ Zob. M. Tanty, Batkany w XX wieku. Dzieje polityczne, Warszawa 2003, s. 316 n.

7 „Pod względem częstotliwości i zakresu zmian system konstytucyjny socjalistycznej Jugosławii jest niezwykle dynamiczny, a kształt przyjmowanych rozwiązań czyni go bardzo oryginalnym. Poszukiwanie form instytucjonalnych odpowiadających w sferze organizacji państwa i społeczeństwa przyjętej przez doktrynę jugosłowiańską interpretacji marksistowskiej teorii rozwoju społecznego uczyniły, że konstytucyjny model tego kraju jest pod wieloma względami niepodobny do tych modeli, które zastosowano w innych państwach socjalistycznych". J. Ciemniewski, Konstytucja Socjalistycznej Federacyjnej Republiki Jugosławii, Wrocław 1975, s. 3. 
W celu ochrony naturalnego środowiska człowieka ludzie pracy, organizacje pracy zespolonej i inne organizacje i wspólnoty samorządowe oraz socjalistyczne społeczeństwo zapewniają warunki ochrony i poprawy naturalnych i innych wartości środowiska człowieka, mających znaczenie dla jego zdrowia, bezpiecznego i twórczego życia oraz pracy obecnego i następnych pokoleń ${ }^{8}$.

Bezpośrednim odniesieniem do kwestii ochrony środowiska był natomiast art. 87 Konstytucji z 1974 r., zgodnie z którym

Ludzie pracy i obywatele, organizacje pracy zespolonej, wspólnoty społeczno-polityczne, wspólnoty lokalne i inne organizacje i wspólnoty samorządowe mają prawo i obowiązek zabezpieczać warunki zachowania i rozwoju naturalnych i stworzonych pracą wartości środowiska człowieka, jak również zwalczać i usuwać szkodliwe następstwa zanieczyszczeń powietrza, ziemi, wód lądowych, morza, hałas lub inne czynniki zagrażające tym wartościom lub życiu i zdrowiu ludzkiemu.

Przytoczony powyżej przepis określał szeroko krąg adresatów zobowiązanych do ochrony środowiska oraz otwarty katalog chronionych wartości. Ustrojodawca jugosłowiański skoncentrował się na ochronie zasobów środowiska, które obiektywnie można uznać za cenne, a skutki ich niskiej jakości za namacalne. Warto jednak zwrócić uwagę na ochronę zasobów naturalnych przewidzianą w przepisach poprzedzających omawianą jednostkę, jak również umiejscowienie art. 87 Konstytucji z 1974 roku. Zgodnie z art. 85

Ziemia, lasy, wody, morze i brzeg morski, kopaliny i inne bogactwa naturalne stanowią dobra powszechnego użytku i tak jak nieruchomości i inne przedmioty o szczególnej wartości kulturalnej i historycznej jako dobro powszechne pozostają pod specjalną ochroną i mogą być wykorzystywane na warunkach i w sposób uregulowany ustawą.

Przepis ten, wraz z regulacjami zawartymi w art. 86 konstytucji z 1974 roku, stanowił podstawę ochrony bogactw naturalnych jako najważniejszych składników środowiska naturalnego 9 . Umiejscowienie przepisu z zakresu ochrony środowiska na końcu rozdziału I Konstytucji, w bezpośrednim sąsiedztwie przepisów regulujących ochronę bogactw naturalnych nasuwa dwa wnioski. Po pierwsze, ówczesny ustrojodawca jugosłowiański przykładał niewielką wagę do ochrony środowiska, wzmiankując jedynie o potrzebie podejmowania takich działań, ale nie regulując ich szczegółowo ani nie odsyłając do regulacji rangi ustawowej. Po drugie, głównym przedmiotem ochrony były bogactwa naturalne i elementy środowiska, których zanieczyszczenie było możliwe do wykrycia zmysłami i jednocześnie brzemienne w skutki. Wskazane wcześniej przepisy stanowiły jedynie dyrektywę ochrony środowiska, nie mogły jednak być podstawą do jakiegokolwiek domagania się efektywnych działań. Docenić należy, że pomimo niedoskonałości

8 Ibidem, s. 58.

9 Art. 86: „Cała ziemia, lasy, wody, morze i wybrzeże morskie, kopaliny i inne bogactwa naturalne muszą być wykorzystywane zgodnie z ustawą regulującą ogólne warunki ich racjonalnego użytkowania i inne interesy ogólne. Ustawą reguluje się sposób zarządzania lasami, użytkami leśnymi i terenami na których występują kopaliny, jak również sposób wykorzystywania lasów, użytków leśnych i kopalin". 
regulacji ustrojodawca uczynił zdecydowany postęp względem poprzednich ustaw zasadniczych, jak również uwzględnić to, że świadomość potrzeby ochrony środowiska dopiero się w społeczeństwach budziła (można nawet przyjąć, że Konstytucja z 1974 roku była dość nowoczesna w tym względzie).

\section{Ochrona środowiska w Konstytucji Słowenii}

Jednym z pierwszych państw, które powstały w wyniku rozpadu Jugosławii była Republika Słowenii. W odróżnieniu od innych krajów byłej Jugosławii, proces uzyskania przez nią niepodległości przebiegał w sposób najmniej burzliwy, gdyż walki zbrojne trwały krótko i przyniosły one (przynajmniej na tle wojny w Bośni czy Kosowie) najmniej ofiar ${ }^{10}$. Zwieńczeniem procesu uzyskiwania niepodległości było przyjęcie 23 grudnia 1991 roku Konstytucji Republiki Słowenii. Od momentu wejścia w życie zawierała ona przepisy odnoszące się bezpośrednio do kwestii ochrony środowiska ${ }^{11}$.

Pierwsze przepisy, na które należy zwrócić uwagę znajdują się w art. 72 Konstytucji Republiki Słowenii, zgodnie z którym

Każdy, zgodnie z ustawą, ma prawo do zdrowego środowiska naturalnego. Państwo dba o zdrowe środowisko naturalne. W tym celu określa warunki i sposoby zarządzania gospodarczego i zarządzania w innych dziedzinach. Ustawa określa na jakich zasadach i w jakim rozmiarze ten, kto wyrządził szkodę w środowisku naturalnym zobowiązany jest do jej naprawienia. Ustawa określa zasady ochrony zwierząt przed znęcaniem się.

Z przytoczonych powyżej przepisów wynika kilka konsekwencji. Przede wszystkim czyste środowisko naturalne jest traktowane jako prawo obywatela. Po drugie, realnie zobowiązanym do czynnej jego ochrony jest państwo. Zobowiązanie to przejawia się w konieczności określenia ustawowo reguł zarządzania środowiskiem, które obejmują wiele płaszczyzn aktywności. Bardzo ważnym jest także umieszczenie w Konstytucji fundamentalnej dla tej gałęzi prawa zasady „zanieczyszczający płaci”12. Inną kwestią, na którą należy także zwrócić uwagę, jest wymienienie jako wartości ochrony zwierząt przed znęcaniem się. Jednak to

10 Zob. P. Mikuli, System konstytucyjny Stowenii, Warszawa 2004, s. 7 n.

11 Konstytucja Republiki Stowenii, przeł. P. Winczorek, Warszawa 2009, s. 10 i n.

12 „Jedną z podstawowych zasad prawa ochrony środowiska jest także zasada »zanieczyszczający płaci«, nazywana również »zasadą odpowiedzialności sprawcy zanieczyszczenia« (Polluter Pays Principle - PPP) [...]. Zasada odpowiedzialności sprawcy występuje w dwóch ujęciach. W ujęciu szerszym - sprawca zanieczyszczenia ponosi odpowiedzialność finansową w pełnym zakresie za szkody spowodowane przez własną działalność niezależnie od tego, czy działalność ta jest zgodna z prawem, czy nie. Znacznie częściej stosowana jest w praktyce definicja zasady w ujęciu węższym, które przewiduje, że zanieczyszczający ponosi finansową odpowiedzialność za przestrzeganie tylko pewnego zakresu standardów. Sprawcą zanieczyszczenia jest podmiot, który bezpośrednio lub pośrednio powoduje szkody w środowisku lub stwarza warunki prowadzące do powstania szkód". P. Korzeniowski, [w:] Prawo ochrony środowiska, red. M. Górski, Warszawa 2014, s. 60-61. 
niejedyne przepisy, które wskazują na silne zainteresowanie ustrojodawcy słoweńskiego kwestiami ochrony środowiska.

Ważną rolę pełni także art. 73 Konstytucji Słowenii, zgodnie z którym „Każdy, zgodnie z ustawą, zobowiązany jest chronić osobliwe i rzadkie twory przyrody oraz pomniki kultury. Państwo i wspólnoty lokalne dbają o zachowanie dziedzictwa przyrodniczego i kulturalnego". W powyższym przepisie wyróżniona została przyroda jako obszar, na którego ochronie władze publiczne powinny szczególnie się koncentrować (terminy „przyroda” i „środowisko” nie są synonimami). W Konstytucji Republiki Słowenii daje się zauważyć podobieństwo do rozwiązań z Konstytucji jugosłowiańskiej, w której to również ochronę ziemi i bogactw naturalnych wymieniono wcześniej niż ochronę środowiska. Zgodnie z art. 70 słoweńskiej ustawy zasadniczej „Korzystanie z dóbr publicznych może podlegać warunkom określonym ustawą. Ustawa określa zasady eksploatacji zasobów naturalnych. Ustawa określa dopuszczalność eksploatacji zasobów naturalnych przez cudzoziemców, a także określa zasady tej eksploatacji”. Podobne rozwiązanie funkcjonowało w ustawie zasadniczej Jugosławii z 1974 roku. Nawiązującym do ochrony środowiska jest również art. 71 słoweńskiej Konstytucji, zgodnie z którym „Ustawa określa szczegółowe zasady użytkowania ziemi tak, by była ona wykorzystywana w sposób jak najbardziej celowy. Ustawa może wprowadzić szczegółowe zasady ochrony ziemi rolniczej. Państwo dba o gospodarczy, kulturalny i społeczny postęp ludności regionów górskich i wyżynnych". Szczególna — bo wyróżniona w ustawie zasadniczej — ochrona ziemi sugeruje, że jest ona jednym z najważniejszych bogactw naturalnych tego kraju (jeśli nie najważniejszym). Istotnie, w Słowenii nie wydobywa się w dużych ilościach żadnych minerałów.

Przytoczone wcześniej przepisy nasuwają kilka wniosków. Po pierwsze, w przypadku Republiki Słowenii jugosłowiańska ustawa zasadnicza częściowo oddziałuje na obecne regulacje, jeśli chodzi o umiejscowienie w przepisach Konstytucji. Po drugie, przepisy Konstytucji Republiki Słowenii przewidują wprost odpowiedzialność za szkodę wyrządzoną w środowisku, jak również niebezpośrednio wyrażają zakaz znęcania się nad zwierzętami, co wskazuje na wysoki stopień szczegółowości (większy niż w przypadku polskich regulacji na poziomie konstytucyjnym). Jednak pomimo dużej szczegółowości trudno jest którykolwiek z przepisów zastosować bezpośrednio.

\section{Ochrona środowiska w Konstytucji Chorwacji}

Ochrona środowiska naturalnego została także uwzględniona w przepisach Konstytucji Republiki Chorwacji z 22 grudnia 1990 roku $^{13}$ obejmujących zasady podstawowe ustroju państwa oraz regulujących podstawowe prawa i wolności obywateli.

13 https://www.sabor.hr/en/constitution-republic-croatia-consolidated-text (dostęp: 15.06.2020). 
Pierwszy z przepisów odnoszący się do ochrony środowiska umieszczony został w rozdziale II art. 3 Konstytucji Republiki Chorwacji, zgodnie z którym

Wolność, równość, równość narodów i równość płci, umiłowanie pokoju, sprawiedliwość społeczna, poszanowanie praw człowieka, nienaruszalność własności, poszanowanie natury i środowiska naturalnego, rządy prawa oraz demokratyczny system wielopartyjny stanowią najwyższe wartości porządku konstytucyjnego Republiki Chorwacji i podstawę wykładni Konstytucji.

Umiejscowienie natury i środowiska naturalnego na równi z równością i wolnością mogłoby wskazywać na bardzo duże zainteresowanie ustrojodawcy chorwackiego zagadnieniami związanymi z ochroną środowiska. Dbałość o środowisko naturalne umieszczona została przed takimi zagadnieniami jak trójpodział władzy, zmiana granic czy prawa do tworzenia partii politycznych.

Drugi z przepisów, który w sposób bezpośredni odnosi się do ochrony środowiska, to umieszczony w rozdziale III Konstytucji Republiki Chorwacji art. 69. Zgodnie z nim „Każdy ma prawo do zdrowego życia. Państwo zapewnia warunki dla zdrowego środowiska. Każdy, zgodnie ze swymi kompetencjami i w ramach swojej działalności, obowiązany jest poświęcać szczególną uwagę ochronie zdrowia publicznego, ochronie przyrody i środowiska". Ten przepis stanowi dyrektywę skierowaną zarówno do władz publicznych, jak i do obywateli oraz osób znajdujących się pod władzą republiki.

Ochrona środowiska jest także ważną przesłanką możliwego ograniczenia wolności działalności gospodarczej. Zgodnie z art. 50 Konstytucji Republiki Chorwacji

W interesie Republiki Chorwacji własność można ograniczyć lub jej pozbawić za zwrotem wartości rynkowej. Swoboda działalności gospodarczej oraz prawa majątkowe mogą zostać w drodze ustawy wyjątkowo ograniczone na rzecz ochrony interesów i bezpieczeństwa Republiki Chorwacji, ochrony przyrody i środowiska naturalnego oraz zdrowia publicznego.

Jednak możliwości ograniczenia wolności działalności gospodarczej nie mogą naruszać jej istoty, co znane jest w nauce prawa konstytucyjnego jako zasada proporcjonalności ${ }^{14}$. Podobna regulacja znajduje się również w art. 31 ust. 3 Konstytucji Rzeczypospolitej Polskiej, zgodnie z którym

Ograniczenia w zakresie korzystania z konstytucyjnych wolności i praw mogą być ustanawiane tylko w ustawie i tylko wtedy, gdy są konieczne w demokratycznym państwie dla jego bezpieczeństwa lub porządku publicznego, bądź dla ochrony środowiska, zdrowia i moralności publicznej, albo wolności i praw innych osób. Ograniczenia te nie mogą naruszać istoty wolności i praw ${ }^{15}$.

14 „Zgodnie z przyjętą w doktrynie praw człowieka tezą, że prawa i wolności nie mają charakteru absolutnego, konstytucja Chorwacji wprowadza w art. 16 zasadę proporcjonalności w ograniczaniu praw i wolności. Postanawia ona, że wolności i prawa mogą być ograniczane tylko ustawą i w celu ochrony wolności i praw innych ludzi, porządku prawnego, moralności publicznej i zdrowia”. J. Karp, M. Grzybowski, System konstytucyjny Chorwacji, Warszawa 2007, s. 26.

15 „Do konstytucyjnego zakazu naruszania istoty prawa, które ograniczane jest przez ustawodawcę, TK (podobnie jak wiele innych sądów konstytucyjnych) dodał jeszcze jedno kryterium wyłączające konstytucyjność ograniczeń — zasadę proporcjonalności. Chodzi w niej o to, aby 
Przepisy chorwackiej ustawy zasadniczej przewidują ochronę środowiska jako jedno z priorytetowych zadań państwa. Konstytucja Republiki Chorwacji nie rozwija jednak tego zagadnienia w sposób, który pozwalałby na zastosowanie któregokolwiek przepisu w sposób bezpośredni. Stanowią one jednak wystarczającą podstawę do tworzenia odpowiednich warunków ochrony środowiska na drodze ustawowej.

\section{Ochrona środowiska w Konstytucji Republiki Serbii}

Ochrona środowiska leży także w obszarze zainteresowań ustrojodawcy serbskiego. Zagadnienie to zostało poruszone w kilku przepisach serbskiej ustawy zasadniczej $^{16}$. Najważniejszym przepisem Konstytucji Serbii w omawianym zakresie jest art. 74, zgodnie z którym

Każdy ma prawo do życia w zdrowym środowisku naturalnym, ma prawo być we właściwym czasie w pełni informowanym o stanie środowiska. Każdy, a szczególnie Republika Serbii i prowincja autonomiczna, ponosi odpowiedzialność za ochronę środowiska naturalnego. Każdy ma obowiązek ochrony i poprawy stanu środowiska naturalnego ${ }^{17}$.

Powyższy przepis wskazuje zarówno na prawo do czystego środowiska, jak i obowiązek każdego do przyczyniania się do zachowania oraz poprawy jego stanu. Wskazuje także na wyraźne uprawnienie do informowania o stanie środowiska naturalnego i ewentualnych zagrożeniach, co stanowi przejaw realizacji III generacji praw człowieka ${ }^{18}$.

Innym ważnym przepisem odnoszącym się do ochrony środowiska jest art. 83 serbskiej ustawy zasadniczej, zgodnie z którym „Gwarantuje się swobodę prowadzenia działalności gospodarczej. Działalność gospodarcza może być ograniczona ustawą w celu ochrony zdrowia ludzi, środowiska naturalnego i bogactw naturalnych oraz bezpieczeństwa Republiki Serbii”. Przepis ten odnosi się do ochrony środowiska w sposób pośredni. Wskazuje on, że wartość, jaką jest środowisko, może być przesłanką do ograniczenia wolności działalności gospodarczej. Ma to stanowić wyjątek od zasady, że wszystko w zakresie prowadzenia działalności gospodarczej, czego prawo nie zabrania, jest dozwolone. Podobny charakter ma ograniczenie zawarte w art. 88 Konstytucji Serbii, zgodnie z którym

Korzystanie i dysponowanie będącymi własnością prywatną gruntami rolnymi, leśnymi i gruntami pod budownictwo miejskie nie podlega ograniczeniom. Ograniczyć sposoby korzystania z gruntów i dysponowania nimi może jedynie ustawa, określając warunki korzystania i dyspo-

ingerencja ustawodawcy w zakres prawa lub wolności konstytucyjnej nie była nadmierna", B. Banaszak, Konstytucja Rzeczypospolitej Polskiej. Komentarz, Warszawa 2009, s. 181.

16 https://biblioteka.sejm.gov.pl/konstytucje-swiata-serbia (dostęp: 15.06.2020).

17 E. Bujwid-Kurek, Konstytucja Republiki Serbii, Warszawa 2018, s. $61 \mathrm{n}$.

18 E. Bujwid-Kurek, Serbia w nowej przestrzeni ustrojowej. Dzieje, ustrój, konstytucja, Kraków 2012, s. 140 n. 
nowania nimi mające zapobiegać szkodom w środowisku naturalnym lub mając na względzie ochronę praw i interesów prawnych innych osób.

Ten przepis z kolei określa przesłanki ograniczenia wolnego korzystania z nieruchomości będących prywatną własnością.

Odniesienia do kwestii ochrony środowiska odnaleźć można także w przepisach określających kompetencje poszczególnych podmiotów. Z uwagi na niejednolity charakter państwa oraz funkcjonowanie samorządu terytorialnego wyróżnione zostały kompetencje republiki, prowincji autonomicznych oraz gmin. Zgodnie z art. 97 ust. 9 Konstytucji Serbii do kompetencji republiki należy „Rozwój zrównoważony; system ochrony i poprawy środowiska naturalnego; ochronę i rozwój flory i fauny; produkcję, handel i transport broni, substancji toksycznych, łatwopalnych, wybuchowych, radioaktywnych i innych niebezpiecznych materiałów". Natomiast w odniesieniu do prowincji autonomicznych istotne znaczenie ma art. 183 ust. 2., który stanowi, że ich zadania obejmują zagadnienia

Rolnictwa, gospodarki wodnej, leśnictwa, łowiectwa, rybołówstwa, turystyki, gastronomii i hotelarstwa, spa i sanatoriów, ochrony środowiska naturalnego, przemysłu i rzemiosła, transportu drogowego, rzecznego i kolejowego, remontów dróg, organizacji targów i innych wydarzeń gospodarczych.

W przypadku samorządu terytorialnego stopnia gminnego zadania w zakresie ochrony środowiska wskazuje art. 190 ust. 2 serbskiej ustawy zasadniczej, zgodnie z którym gmina „Troszczy się o ochronę środowiska naturalnego, chroni przed klęskami żywiołowymi i innymi. Chroni dobra kultury mające znaczenie dla gminy". Powyższe przepisy, mimo że poruszają problematykę ochrony środowiska, nie określają w sposób wyczerpujący czynności, jakie władze publiczne powinny podejmować w tym zakresie, oraz uprawnień przysługujących obywatelom. Omawiane przepisy nie dają także bezpośredniej podstawy do wysuwania roszczeń (poza kwestią informacji o środowisku) w kierunku władz publicznych o działanie lub zaniechanie w zakresie ochrony środowiska. Niedoskonałość regulacji w tej kwestii być może wynika z tego, że Republika Serbii w obecnej formie jest państwem stosunkowo młodym, mającym trudne doświadczenia w historii najnowszej ${ }^{19}$.

\section{Ochrona środowiska w Konstytucji Republiki Macedonii}

Macedonia jest jednym z państw powstałych w wyniku rozpadu Jugosławii. Secesja Republiki Macedonii przebiegała relatywnie spokojnie, choć do dziś istnieje spór z Grecją o nazwę państwa (tożsamą z nazwą jednego z regionów Grecji $^{20}$. Nowo powstałe państwo ma konstytucję, przyjętą 17 listopada 1991

19 Zob. J. Wojnicki, System konstytucyjny Serbii i Czarnogóry, Warszawa 2005, s. 19.

20 Zob. J. Wojnicki, System konstytucyjny Macedonii, Warszawa 2009, s. 13 n. 
roku, w której oprócz zagadnień podziału władzy czy praw i wolności, określono także stosunek władz do kwestii ochrony środowiska.

Zgodnie z art. 8 macedońskiej Konstytucji ${ }^{21}$ „Zasadniczymi wartościami porządku konstytucyjnego Republiki Macedonii są: [...] harmonijna gospodarka przestrzenna, ochrona i poprawa środowiska naturalnego i przyrody". Macedoński ustrojodawca wskazał ochronę środowiska w jednym rzędzie z gospodarką przestrzenną jako najważniejsze wartości konstytucyjne, co sugeruje, że w jego pojęciu są to zagadnienia ściśle ze sobą związane. $Z$ cytowanego wcześniej przepisu wynika także, że ochrona środowiska wykonywana przez władze publiczne przejawia się przede wszystkim jako ochrona konserwatorska, dążąca do zachowania środowiska i przyrody w stanie niepogorszonym.

Równie ważne przepisy Konstytucji Republiki Macedonii zawarte są w art. 43, zgodnie z którym „każdy człowiek ma prawo do zdrowego środowiska naturalnego. Każdy jest obowiązany chronić środowisko naturalne i przyrodę oraz przyczyniać się do poprawy ich stanu. Republika zapewnia warunki realizowania prawa obywateli do zdrowego środowiska naturalnego". Powyższe przepisy wskazują, podobnie jak ma to miejsce w innych ustawach zasadniczych państw byłej Jugosławii, prawo do czystego środowiska i obowiązek dbania o nie. Konstytucja Republiki Macedonii zobowiązała także władze publiczne do zapewnienia obywatelom możliwości zrealizowania swoich uprawnień w zakresie ochrony środowiska.

Wskazane przepisy są jedynymi, które w sposób bezpośredni odnoszą się do ochrony środowiska. Ich lakoniczność nie pozwala na bezpośrednią ochronę środowiska, nie rodzi także podstaw do roszczeń (poza bliżej nieokreślonym zapewnieniem warunków do realizowania praw obywateli do zdrowego środowiska) obywateli względem władz publicznych o działanie lub zaniechanie. W sposób pośredni do kwestii ochrony środowiska odnosi się z kolei art. 55 Konstytucji Republiki Macedonii, zgodnie z którym „Wolność rynku i swobodę przedsiębiorczości można ograniczyć tylko ustawą z powodu konieczności obrony Republiki, ochrony przyrody i środowiska naturalnego albo zdrowia ludności". Powyższe jest znanym z innych porządków prawnych ograniczeniem wolności gospodarczej, niebudzącym większych wątpliwości. Inny przepis macedońskiej ustawy zasadniczej poruszający w sposób pośredni zagadnienia z obszaru ochrony środowiska to art. 56, zgodnie z którym „Wszelkie bogactwa naturalne w Republice, świat roślin i zwierząt, dobra wspólnego użytku, podobnie jak przedmioty i obiekty o szczególnym znaczeniu dla kultury i historii, określone przez ustawę, stanowią dobra ogólnego interesu Republiki i korzystają ze szczególnej ochrony”. Podobnie jak poprzednio wskazane przepisy, jest on ogólnikowy, niedający podstawy do roszczeń o działanie lub zaniechanie władz publicznych, niewyznaczający standardów „szczególnej ochrony” ani nieokreślający, co mogłoby być punktem odniesienia.

21 Ibidem. 


\section{Ochrona środowiska w Konstytucji Bośni i Hercegowiny}

Szczególną formę ma ustawa zasadnicza Bośni i Hercegowiny. Stanowi ona załącznik do układu pokojowego z Dayton, zawartego w 1995 roku ${ }^{22}$. Wynika to z faktu trwającego kilka lat konfliktu pomiędzy Serbami oraz Chorwatami i Bośniakami, którzy zamieszkiwali ten kraj. Bośnia i Hercegowina jest państwem federalnym, w przypadku którego tylko niewielkie kompetencje nalezą do władz centralnych. Prawdopodobnie z tego powodu ochrona środowiska obecnie nie stanowi przedmiotu szczególnego zainteresowania ustrojodawcy bośniackiego.

Jedynym przepisem bośniackiej ustawy zasadniczej odnoszącym się bezpośrednio do ochrony środowiska jest art. 3 ust. 2 lit. c), zgodnie z którym

Podmioty zapewnią bezpieczne i bezpieczne środowisko dla wszystkich osób w ich odpowiednich jurysdykcjach, utrzymując cywilne organy ścigania działające zgodnie z międzynarodowo uznanymi standardami oraz z poszanowaniem międzynarodowo uznanych praw człowieka i podstawowych wolności, o których mowa w artykule II powyżej oraz podejmując inne odpowiednie środki ${ }^{23}$

Powyższy przepis wskazuje na kilka kwestii. Po pierwsze, środowisko należy do kategorii praw człowieka, które podlegają ochronie. Po drugie, bośniacka ustawa zasadnicza zawiera odesłanie do norm prawa międzynarodowego w zakresie standardów ochrony środowiska, co należy uznać za niewątpliwą zaletę Konstytucji Bośni i Hercegowiny. Ustrojodawca zobowiązał także podmioty składowe federacji do tworzenia i utrzymywania organów administracji publicznej zajmujących się ochroną środowiska. Przewidział on także możliwość stosowania wszelkich niezbędnych środków, dzięki którym można osiągać cele związane z ochroną środowiska, co również należy uznać za dobre rozwiązanie. Cytowane przepisy są więc dobrą podstawą do stworzenia efektywnego systemu ochrony środowiska, same jednak nie są podstawą do konkretnych działań w tym zakresie. Mając na uwadze okoliczności powstania ustawy zasadniczej Bośni i Hercegowiny, należy uznać przyjęte rozwiązania w tym zakresie za dość dobre.

\section{Ochrona środowiska w przepisach Konstytucji Czarnogóry}

Czarnogóra należy do najmłodszych z omawianych państw, jako że powstała kilkanaście lat po rozpadzie Jugosławii, w 2006 roku. W odróżnieniu od innych

22 https://peacemaker.un.org/bosniadaytonagreement95 (dostęp: 15.06.2020).

23 ,The Entities shall provide a safe and secure environment for all persons in their respective jurisdictions, by maintaining civilian law enforcement agencies operating in accordance with internationally recognized standards and with respect for the internationally recognized human rights and fundamental freedoms referred to in Article II above, and by taking such other measures as appropriate", zob. http://www.ccbh.ba/osnovni-akti/ustav/?title=preambula\&lang=en (dostęp: 28.09.2018). 
państw regionu jej droga do niepodległości przebiegała pokojowo ${ }^{24}$. Od 22 października 2007 roku Republika Czarnogóry posiada ustawę zasadniczą, w której również znajduje się kilka odniesień do zagadnień z zakresu ochrony środowiska.

Pierwsze z nich można odnaleźć już w preambule do ustawy zasadniczej, zgodnie z którą ,,państwo jest odpowiedzialne za zachowanie natury, stanu środowiska, zrównoważony rozwój, zrównoważony rozwój wszystkich regionów i regionów ustanowienie sprawiedliwości społecznej [...]"25. To pierwsza ustawa zasadnicza, która podobnie jak ma to miejsce w Konstytucji RP, odwołuje się do zasady zrównoważonego rozwoju. Nie jest to jednak pojęcie sprecyzowane w polskim porządku prawnym, nie ma też jego rozwinięcia w czarnogórskiej ustawie zasadniczej. Umieszczenie zagadnienia ochrony środowiska już w preambule sugeruje, że jest to kwestia istotna dla czarnogórskiego ustrojodawcy.

Bezpośrednio do ochrony środowiska odnosi się z kolei art. 23 czarnogórskiej ustawy zasadniczej, zgodnie z którym

Każdy ma prawo do zdrowego otoczenia. Każdy ma prawo do otrzymania aktualnych i wyczerpujących informacji na temat stanu środowiska, aby wpłynąć na podejmowanie decyzji dotyczących problemów środowiska i prawnej ochrony tych praw. Wszyscy, w szczególności państwo, zobowiązani są do zachowania i ulepszania środowiska.

Przepis oprócz gwarancji prawa do zdrowego otoczenia zawiera prawo do informacji o stanie środowiska. Jest to także zabezpieczenie prawa do udziału społeczeństwa w ochronie środowiska. Cytowany przepis jest także zaadresowany do władz publicznych, które są zobowiązane do działania na rzecz poprawy stanu środowiska.

Konstytucja Republiki Czarnogóry w sposób pośredni odnosi się do ochrony środowiska w kontekście swobody gospodarczej, co jest rozwiązaniem znanym z konstytucji innych państw powstałych z byłej Jugosławii. Zgodnie z art. 59 „Gwarantuje się wolność przedsiębiorczości. Wolność przedsiębiorczości może być ograniczona tylko wtedy, gdy jest to konieczne, aby chronić zdrowie ludzi, środowisko, zasoby naturalne, dziedzictwo kulturowe lub bezpieczeństwo i obrona Czarnogóry". Innym przepisem odnoszącym się pośrednio do ochrony środowiska jest art. 133 Konstytucji Republiki Czarnogóry, zgodnie z którym

Stan wyjątkowy może być ogłoszony na terytorium lub części terytorium Czarnogóry w przypadku: 1) klęski żywiołowej; 2) wypadku technicznego i środowiskowego oraz epidemii; 3) większego zakłócenia publicznego spokoju i porządku; 4) naruszenia lub próby zniesienia porządku konstytucyjnego.

Cytowany przepis określa przesłanki wprowadzenia stanu wyjątkowego, wśród których jedną z ważniejszych jest zagrożenie dla środowiska. Czarnogórska usta-

${ }^{24}$ Zob. J. Wojnicki, System konstytucyjny Czarnogóry, Warszawa 2012, s. 5.

25 http://www.skupstina.me/index.php/en/ustav-crne-gore (dostęp 28.09.2018). 
wa zasadnicza nie rozwija tego zagadnienia w kontekście ochrony środowiska, stąd niezbędnym będzie rozszerzenie go w aktach normatywnych niższego rzędu.

\section{Ochrona środowiska w przepisach Konstytucji Republiki Kosowa}

Republika Kosowa powstała w wyniku jednostronnej deklaracji niepodległości w 2008 roku. Nie jest ona jednak uznawana przez wszystkie państwa. Na jej terytorium przez wiele lat rozgrywał się konflikt etniczny pomiędzy Serbami i Albańczykami zamieszkującymi ten kraj. Obecnie jednak Republika Kosowa ma struktury i organy państwa, a najważniejszym aktem prawnym jest konstytucja, która również odnosi się do ochrony środowiska.

Zgodnie z art. 7 kosowskiej ustawy zasadniczej

Konstytucyjny porządek Republiki Kosowa opiera się na zasadach wolności, pokoju, demokracji, równości, poszanowania praw człowieka i wolności oraz państwa prawa, niedyskryminacji, prawa własności, ochrony środowiska, sprawiedliwości społecznej, pluralizmie, rozdziale władzy państwowej i gospodarki rynkowej ${ }^{26}$.

Z powyższego można wysnuć wniosek, że ochrona środowiska należy do podstawowych zadań Republiki Kosowa, gdyż wymieniona jest obok takich wartości jak sprawiedliwość społeczna, państwo prawa czy prawo własności. Innym przepisem bezpośrednio odnoszącym się do ochrony środowiska jest art. 52, zgodnie z którym

1. Natura i różnorodność biologiczna, środowisko i dziedzictwo narodowe należą do wszystkich. 2. Każdy powinien mieć możliwość bycia wysłuchanym przez instytucje publiczne i rozważenia swoich opinii w kwestiach mających wpływ na środowisko, w którym żyją. 3. Wpływ na środowisko jest uznawany przez instytucje publiczne $\mathrm{w}$ ich procesach decyzyjnych.

Przyjęte rozwiązania zawierają prawo do informacji o środowisku i prawo do udziału w jego ochronie, co należy traktować jako dobre rozwiązanie. Brakuje natomiast gwarancji wykonywania tego prawa czy wyznaczenia instytucji egzekwujących przyznane konstytucyjnie uprawnienia (na przykład poprzez wskazanie konieczności powołania organów).

Innych odniesień do ochrony środowiska, zarówno bezpośrednich jak i pośrednich, w kosowskiej ustawie zasadniczej nie ma. Przytoczone wyżej dwa przepisy pomimo dobrych zamysłów samodzielnie nie przedstawiają wystarczającej gwarancji skutecznej ochrony środowiska. Brakuje na przykład znanej z innych konstytucji możliwości ograniczenia wolności gospodarczej ze względu na ochronę środowiska. Sama Konstytucja Republiki Kosowa nie jest zatem wystarczającą podstawą efektywnej ochrony środowiska.

${ }^{26}$ http://www.kuvendikosoves.org/?cid=2,1058 (dostęp: 28.09.2018). 


\section{Podsumowanie}

Państwa byłej Jugosławii w różny sposób uregulowały kwestie ochrony środowiska w swoich ustawach zasadniczych. Przedstawione na łamach niniejszej publikacji przepisy nasuwają kilka wniosków. Po pierwsze, regulacje zawarte w Konstytucji Jugosławii w znikomy sposób korespondują z obecnymi unormowaniami w tym zakresie. Każde państwo w różny sposób określiło zagadnienia związane z ochroną środowiska. Po drugie - istnieje konieczność stworzenia ustawodawstwa całościowo regulującego materię ochrony środowiska, gdyż żadna z omawianych konstytucji nie wyczerpuje tego zagadnienia. Istniejące przepisy niekiedy gwarantują obywatelom uprawnienia w zakresie ochrony środowiska w sposób fragmentaryczny, jednak bez ustawodawstwa szczegółowego niemożliwa jest w żadnym państwie efektywna ochrona środowiska. Co więcej, w niektórych państwach ustawa zasadnicza jedynie zdawkowo odnosi się do kwestii środowiska, nie dając żadnych istotnych gwarancji jego ochrony. Po trzecie, daje się zauważyć donioślejszą rolę przepisów z zakresu ochrony środowiska w porządkach ustrojowych Słowenii i Chorwacji względem reszty państw byłej Jugosławii, zwłaszcza w odniesieniu do Republiki Macedonii. Pozytywnie należy ocenić także regulacje przyjęte przez ustrojodawcę Czarnogóry, zawierające rozbudowane uprawnienia obywateli do czystego środowiska.

Trudno oczekiwać, aby ustawa zasadnicza każdą kwestię określała szczegółowo. Jednak niektóre z rozwiązań, jak na przykład prawo do informacji o stanie środowiska, obowiązek uwzględniania międzynarodowych standardów ochrony środowiska czy prawo do udziału w jego ochronie, są rozwiązaniami zasługującymi na uwagę ustrojodawcy polskiego jako proponowane prawa, którymi można by uzupełnić polską ustawę zasadniczą.

\section{Bibliografia}

\section{Literatura}

Banaszak B., Konstytucja Rzeczypospolitej Polskiej. Komentarz, Warszawa 2009.

Bujwid-Kurek E., Konstytucja Republiki Serbii, Warszawa 2018.

Bujwid-Kurek E., Serbia w nowej przestrzeni ustrojowej. Dzieje, ustrój, konstytucja, Kraków 2012.

Ciemniewski J., Konstytucja Socjalistycznej Federacyjnej Republiki Jugosławii, Wrocław 1975.

Górski M., Prawo ochrony środowiska, Warszawa 2014.

Karp J., Grzybowski M., System konstytucyjny Chorwacji, Warszawa 2007.

Konstytucja Federacyjnej Ludowej Republiki Jugosławii, przeł. N. Sandulovič, E. Kamiński, Warszawa 1957.

Konstytucja Republiki Stowenii, przeł. P. Winczorek, Warszawa 2009.

Mikuli P., System konstytucyjny Stowenii, Warszawa 2004.

Pacuła P., Kosowo: problemy teraźniejszości, wyzwania przyszłości, „Bezpieczeństwo Narodowe” 22, 2012.

Rutyna-Frelek Z., Powstanie Socjalistycznej Federacyjnej Republiki Jugostawii, Warszawa 1985. Tanty M., Bałkany w XX wieku. Dzieje polityczne, Warszawa 2003. 
Wojnicki J., System konstytucyjny Czarnogóry, Warszawa 2012.

Wojnicki J., System konstytucyjny Macedonii, Warszawa 2009.

Wojnicki J., System konstytucyjny Serbii i Czarnogóry, Warszawa 2005.

\section{Źródła internetowe}

http://www.ccbh.ba/osnovni-akti/ustav/?title=preambula\&lang=en (dostęp: 28.09.2018).

http://www.skupstina.me/index.php/en/ustav-crne-gore (dostęp: 28.09.2018).

http://www.kuvendikosoves.org/?cid=2,1058 (dostęp: 28.09.2018).

https://www.sabor.hr/en/constitution-republic-croatia-consolidated-text (dostęp: 15.06.2020).

https://peacemaker.un.org/bosniadaytonagreement95 (dostęp: 15.06.2020).

https://biblioteka.sejm.gov.pl/konstytucje-swiata-serbia (dostęp: 15.06.2020). 